\title{
Africa and Cultural Authenticity
}

\author{
Ibekwe Ephraim $\mathbf{U}^{1}$ \\ Urban University Rome: Department of Religious Studies, Italy. \\ Email:udo.chukss@yahoo.com
}

\begin{abstract}
The media outlets all over the world project Africa as inferior and mere notion of the continent brings to mind war- Hunger, Malnourishment, deadly diseases, religious fanaticism etc. These and many other pessimistic notions about Africa live a remarkable question 'Can anything good come from Africa? Hence, this article pays particular attention to the authenticity of African Culture. It maintains that amidst ferocious criticisms on the African Continent, Her cultural values remain inestimable and thus second to none in the whole world. This article exposes the different problems that exist in African culture including the ones caused by Africans themselves, those caused remotely by colonialism or recently by the West. Hence this article is a call back to cultural authenticity as that would be the only saviour of the African continent. It believes that truly Africa can still be authentic and can remain true to her values and cultural Heritage.
\end{abstract}

Keywords: Africa, Culture and authenticity.

Licensed: This work is licensed under a Creative Commons Attribution 4.o License.

\section{Introduction}

Africa has had a terrible experience of the destruction of life and community, cultural heritage and cultural values. The peculiar institution of the slave trade was actually an unprecedented enemy of life and community in Africa. Colonialism and racism targeted life, human dignity and human rights of the Africans. Since the independence of African nations, life has continued to be destroyed, distorted and harmed in so many cruel ways by our fellow African leaders. Hence, Africa is seen today in the world community as a continent of misery. Many statistics trumpet this reality. Ecological disasters, such as flood and drought, bring agricultural production in many regions of the continent to a standstill. Warring groups prevent farmers from cultivating fertile land. Africa can no longer feed its teeming millions; economic depression of unparallel proportions makes existing authoritarian regimes more repressive. Dictatorships and civil wars uproot women, men, and children from ancestral homes to neigbouring countries. In Nigeria, Sierra Leone, Somalia, Sudan, Angola and Liberia it is difficult to silence the guns. In Rwanda and Burundi ethnic strife makes it impossible for BaHutu and Batutsi to live in peace, in Nigeria the activities of the Fulani herds men have left many homes displaced and continued to cause security tension. Machetes, den-guns and automatic rifles are freely used in the barbaric massacre of hundreds of thousands of children, women and men. Even the Kukumba and Namumba of Ghana and Togo settle scores which have been simmering since the abolition of the slave trade. Refugees in Africa number over seven million; that is about 50 percent of the world population of refugees.

Intellectuals whose role in the development of culture is irreplaceable are driven away from their homeland or flee the shores of Africa for greener pastures abroad [brain drain]. Apart from sports and music one hardly hears any positive news item about Africa. For their part, when Africans narrate their plight in these trying times, they sound even more pessimistic. The marginalized elite who fled their countries to maintain a relatively decent living abroad make uncomplimentary comparisons between their host countries and their fatherland. This is the wounded face of Africa frequently portrayed in the mass media.

The mere mention of Africa reminds everyone of the blackness of the skins of Africans, the darkness that hovers around the continent, the war-prone zones of the continent, poverty and malnourishment. The headlines of the media-BBC, CNN, ALJAZEEERA showcases the naked bodies of malnourished African Children and the many of them suffering from various degrees of diseases. For many, nothing good can come 
out of Africa. This has been a total misrepresentation of the African nation. It is good to note that the richness of the values and cultural heritages of the continent cannot be compared to any in the universe. The images, pictures and videos in the media are only misrepresentations, unnecessary emphasis and excessive exaggerations of the events in the continent that is only bent in total destruction of the African image.

While it is undeniable to say that Africa is a victim of marginalization by the West, it is good also to point out unequivocally that the African Man has failed in his duty-A duty of elevating Africa. One of the root causes of the many anti-life forces, systems and problems in Black Africa has been our failure to embark on the movement of re-awakening our own cultural, ethical/moral, religio-politico values and to construct the future on them. As it is known that no sane society chooses to build its future on foreign cultures [borrowed culture], values or systems, such society may not succeed. Every society is obliged to search deep in its own history and culture in order to discover the values upon which its development and liberation, its civilization and its identity should be based. To do otherwise is nothing less than communal suicide.

In rebuilding Africa we must put an end to lamentation and the dirge that has formed the headlines and head sentences of our scripts and public speeches. Most African writings begin by denouncing the colonial masters and the white man, laying blames on them for a lot of deep rooted issues even to the extent of blaming them for Africa's existence. We do this and fail to seek for ways forward. But at the end of the day we should realize that the colonial masters only contributed about 20 percent of the problems of Africa, the rest 80 are not alien but African-self-caused problems. On this Basil Davidson writes that the problems and solutions of today have to be envisaged within a historical framework, no matter what contribution an external world may have made. This is the legacy the present generation must live behind, a legacy of non- pretence, dedication, and above all that of authenticity, one lived by our founding fathers like Mandela, Luther etc. However, Walter Rodney is of the view that citizens of Africa should resists all temptations to live their lives life as permanent victims, angry accusers and frowning imitators of Europe. He echoes thus,

"come then, comrades, the European game has finally ended...look at them today swaying between atomic and spiritual disintegration... we must find something different. We today can do everything so long as we are not obsessed by the desire to catch up with Europe. We have taken the liberty at this point of changing Europe to Europe/America... The third world faces Europe/ America like a colossal mass whose aim should be to try to resolve the problems to which Europe/America has not been able to find the answers to. Let us not pay tribute to Europe and America by creating states, institutions and societies which draw their inspiration from her...If we want humanity to advance a step further, if we want to bring it up to a different level then we must invent, we must make discoveries...we must turn over a new leaf and we must work out new concepts” Rodney (2005).

The only way to carry out this revolution is not again by guns or ammunitions or by violence but a call to redefine the African Geist [the African Spirit]. The greatest war has been fought by young men and women of any society who in themselves have awakened the inner spirit and made the decision to be men of quality, resilience, of impeccable character and unwavering determination such that in the difficult times when they sought total emancipation from slavery and poverty, from racism and degradation of the human person, they were able to hold firm to their goals and insist on victory even if it means death. This must be the goal of every African Child-old and young alike. One of the ways to achieve this is by revisiting our culture and values. This is because the culture of the African Man lies at the zenith of his way of life. In fact culture constitutes the African Man and it is in courageous and creative attempts to respond to the magnificent summon of cultural authenticity that the African can begin to break the chains of economy and shake the foundations of all human exploitation. By doing so, the African will be prepared to give up all the deadly games of the last-Millennia, seeking out new means of defence, new forms of struggle, new pathways toward revolution, and new visions of what truly human society demands of us-as society whose moral values cannot be compromised with imported morality. In the bid to rebuild the African Continent, we seek to rebuild our culture-hence the preoccupation of this article-Africa and Cultural Authenticity.

\subsection{Africa}

In discussing the concept of Africa in this article, we shall not concern ourselves with the geographical constitution of the continent rather a contextual analysis would be adopted. Africa in this article shall refer to Black Africa, South of the Sahara. Different ethnic groups and cultures have shaped Africa- South of the Sahara. The region has also been influenced by non-African culture. At the same time, African cultural influences have spread to other parts of the world. Africa has remained victim of colonialism and the negative impacts have left scares on the African Soil. The serious study of African Cultures began several decades ago with a marked emphasis on general conclusions about Black Africa. Black Africa has had a terrible experience of the destruction of cultural values. The weird establishment of the slave trade was an enemy of life, values, community and communality in African continent. With Colonialism and racism, there was massive exploitation and disrespect for human dignity of Africans. Since the independence of African nations, life has continued to be destroyed and Culture relegated, distorted and harmed in so many cruel ways by our fellow African leaders, often supported by foreign self seekers. To be able to bring back sanity and serenity, to be able to restore and heal Africa, there must be reference made to African Culture- a return back to cultural authenticity. However, Magesa (1997) notes that "the problems and solutions of today have to be envisaged 
within a historical frame work, an indigenous historical frame work, no matter what contribution an external world may have made" One of the root causes of the hydra headed problems with special reference to culture and values in Black Africa has been our failure to embark on the movement of re-awakening our own cultural values and construct the future on them. Thus, "No sane society chooses to build its future on foreign cultures, values or systems. Every society is obliged to search deep in its own history, culture, religion and morality in order to discover the values upon which its development and liberation, its civilization, and its identity should be based"(Magesa, 1997).

By searching deep into the cultural values of Africa, we discover, the beauty of our language, the dignity of human life and respect for elders, the good sense of hospitality, regard for morality, the genius of our ancestors, the splendor of hard work and the impact of peace and justice. Re-discovering these would lead us back to Authenticity- [not only in respect to culture but also to the personhood and a better and improved African society]

\subsection{Authenticity}

In the Oxford English Dictionary authenticity is first defined as being "in accordance with fact, as being true in substance." The dictionary defines authenticity again "as being what it professes in origin or authorship; as being genuine." In this second definition we get the sense that authenticity is rooted in creativity and selfexpression rather than in conformity to social forces. A third definition offered by the Oxford English Dictionary characterizes the authentic as that which is "real, actual." Here, the authentic stands against replicas, pretence, and posing - a narrative common in popular culture. Synonymously, the word suggests the genuineness of a thing, unique quality, the validity, accuracy and faithfulness of a thing/person to itself and what it represents. What each of these definitions share in common is the reification of authenticity in everyday culture and discourse. Authenticity is to be understood as an inherent quality of some object, person or process. As a philosophical concept, it denotes the genuine, original, true state of human existence. The concept arises from the insights that human beings generally live or exist in an inauthentic way and that the genuine sense of self and its relationship with others have been lost, hence the quest for its restoration.

Beyond our belief that authenticity is a socially constructed phenomenon, we recognize that authenticity is "ultimately an evaluative concept, however methodical and value-free many of the methods for establishing it may be" (Lee, 2003). Authenticity may be seen as some sort of ideal, highly valued and sought by individuals and groups as part of the process of becoming. Alternatively, authenticity is often something strategically invoked as a marker of status or method of social control. Authenticity is not so much a state of being as it is the objectification of a process of representation, that is, it refers to a set of qualities that people in a particular time and place have come to agree represent an ideal or exemplar. As culture changes - and with it, tastes, beliefs, values, and practices-so too do definitions of what constitutes the authentic. Authenticity is thus a "moving target" (Richard, 1997). Sociology of authenticity must attend to the socially constructed, evaluative, and mutable character of the concept, as well as its impact on a number of social dimensions with culture at the peak.

\subsection{The Value of Authenticity}

Authenticity can refer to a moral identity functioning as a source for normativity, to the impetus of the cultural movement toward self-realization typical of the twentieth century and the force of example and the ideal and practice of exemplarity. Authenticity is both a moral quest toward the value and practice of selfdiscovery and an effort to attain identity and stability in the ever-fluctuating and (relatively) anchor-less maelstrom of fleeting trends, panics, and doubts of postmodern society. By de-emphasizing play, irony, pastiche, style, and conspicuous display of taste in subcultures, and by emphasizing instead existential and ideological commitment to a movement's ideals. Any intelligent reflection on the value of authenticity has to be carried out while keeping in mind the importance of its counterpart: inauthenticity. Inauthenticity is not only inevitable, but, even desirable at times. This view was championed by Dennis Waskul. According to him, inauthenticity, insincerity, or simply the necessity to abandon moral struggles and say "to hell with it!" are common features of everyday life, and even of a good life. To explain this important point Waskul appropriated a contrived auto-ethnographic exploration, a breaching social experiment, and a flight of fancy. As he tries to stay true to himself and others for a full day Waskul finds himself incapacitated by the continuous struggles to define what is authentic and morally honest versus what is inauthentic and socially right. And after angering students, coworkers, and family members with his authentic and sincere ways Waskul concludes that not only is inauthenticity necessary, it is often desirable.

Discussions of authenticity and inauthenticity are legion within the ever-expanding field of cultural studies, and especially within the interdisciplinary subfield of subculture studies, classic ethnographic accounts of music-based subcultures, countercultures, lifestyle enclaves, scenes, or simply peer groups. Analysis have shown that concerns with authenticity lie at the roots of group membership, group collective identity and values, personal and social identity formation and maintenance, and status . But aside from the more microsociological concerns with authenticity as congruence to group ideology and with the personal authenticity of group members, the very existence of subcultures and the great diversity of contemporary lifestyle projects of the self bears testament to the widespread preoccupation with individual self-realization, choice, self- 
expression, and connectedness with like-minded and like-hearted others, typical of late modern culture and society. Systematic discussions on authenticity have become more common within social psychology and the sociology of culture only in the last fifteen years or so. But the topics of tourists' experiences of authenticity and inauthenticity, of travel as a quest for the authentic and of the authenticity of cultural expressions, rituals, and artefacts produced for tourists have been a staple of research and debates in the interdisciplinary field of travel and tourism studies for quite a bit longer. Explorations of authenticity in this field can hardly come into their own without taking into account. This analysis emphasizes the fact that authenticity and culture are closely related.

\subsection{Authenticity and Philosophy}

The concept of Authenticity has remained a reoccurring term or concept in the field of philosophy. The importance of this concept in philosophical history cannot be overemphasized as it is one of those that suggest pragmatism, given the erroneous conception of philosophy as one filled with theories, however Authenticity suggests pragmatism-it is action oriented. For example, Socrates's dictums, such as, "Unexamined life is not worth living," or "Know yourself," can be seen as his attempts to investigate the self as an entity by subjecting it to scrutiny and in the end to lead others to the discovery of the authentic self and way of life. Kierkegaard examined the loss of the genuine self in the mass, in society, and tried to present the process of recovering the authentic self within a theistic context. Other existential thinkers such as Sartre, Nietzsche, Paschal, Heidegger and karl Jasper equally discussed the issue of authenticity and developed various ways to deal with the issue.

The German term eigentlich (authentic) contains the element of eigen ("one's own"). Authenticity, thus, includes the element of "one's own unique self." Accordingly, recovery of authenticity implies the recovery of one's own unique identity. This particular concept is of paramount importance to our work. When existential thinkers speak of authenticity, they often include this element and contrast the unique self against the concept of mass, in which the individual is no more than just a number.

Existential philosophers build the element of authenticity into their own philosophical thought and configure it according to central themes of their works. Accordingly, the way each philosopher deal with authenticity is different and expositions of their views of authenticity are not straightforward. Our concept use of the term authenticity boarders around Kierkegaard, though not limited to him.

\subsection{Kierkegaard}

One of the philosophers that occupied themselves with the concept of authenticity is Soren Kierkegaard. He criticized the philosophical systems that were brought on by philosophers such as Hegel before him and the Danish Hegelians, although Kierkegaard respected the philosophy of Kant. He measured himself against the model of philosophy which he found in Socrates, which aims to draw one's attention not to explanatory systems, but rather to the issue of how one exists. One of Kierkegaard's recurrent themes is the importance of subjectivity, which has to do with the way people relate themselves to (objective) truths. In Concluding Unscientific Postscript to Philosophical Fragments, he argues that "subjectivity is truth" and "truth is subjectivity." What he means by this is that most essentially, truth is not just a matter of discovering objective facts. While objective facts are important, there is a second and more crucial element of truth, which involves how one relates oneself to those matters of fact. Since how one acts is, from the ethical perspective, more important than any matter of fact, truth is to be found in subjectivity rather than objectivity (Howard and Edna, 1975).

\subsection{Authenticity and Individuality}

Kierkegaard emphasized the power of individuality as a call to Authenticity. For him, true individuality is called selfhood. Becoming aware of true self is the true task and endeavour in life-it is an ethical imperative, as well as preparatory to a true religious understanding. Individuals can exist at a level that is less than true selfhood. One can live, for example, simply in terms of pleasures - the immediate satisfaction of desires, propensities, or distractions. In this way, people glide through life without direction or purpose. To have a direction, one must have a purpose that defines for him the meaning of his lives.

In Sickness Unto Death, specifically, Kierkegaard deals with the self as a product of relations. In this sense, a human results from a relation between the infinite (Noumena, spirit, eternal) and finite (Phenomena, body, temporal). This does not create a true self, as a human can live without a "self" as he defines it. Instead, the Self or ability for the self to be created from a relation to the Absolute or God (the Self can only be realized through a relation to God) arises as a relation between the relation of the finite and Infinite relating back to the human. This would be a positive relation.

An individual person, for Kierkegaard, is a particular that no abstract formula or definition can ever capture. Including the individual in "the public" (or "the crowd" or "the herd") or subsuming a human being as simply a member of a species is a reduction of the true meaning of life for individuals. What philosophy or politics try to do is to categorize and pigeonhole individuals by group characteristics instead of individual differences. For Kierkegaard, "those differences are what make people who they are"(Alexander, 1999). 
Kierkegaard's critique of the modern age, therefore, is about the loss of what it means to be an individual. Modern society contributes to this dissolution of what it means to be an individual. Through its production of the false idol of "the public," it diverts attention away from individuals to a mass public that loses itself in abstractions, communal dreams, and fantasies. It is helped in this task by the media and the mass production of products to keep it distracted. Although Kierkegaard attacked "the public," he is supportive of communities.

\subsection{Authenticity and African Culture}

Authenticity has been associated with various cultural activities. For Sartre, Jazz music, for example, was a representation of freedom; this may have been in part because Jazz was associated with African-American Culture, and was thus in opposition to Western culture generally, which Sartre considered hopelessly inauthentic. Theodor Adorno, however, another writer and philosopher concerned with the notion of authenticity, despised Jazz music because he saw it as a false representation that could give the appearance of authenticity but that was as much bound up in concerns with appearance and audience as many other forms of art. Heidegger, in his later life, associated authenticity with non-technological modes of existence, seeing technology as distorting a more "authentic" relationship with the natural world.

Most writers on inauthenticity in the twentieth century considered the predominant cultural norms to be inauthentic; not only because they were seen as forced on people, but also because, in themselves, they required people to behave inauthentically towards their own desires, obscuring true reasons for acting. Race relations are seen as another limit on authenticity, as they demand that the self engage with others on the basis of external attributes. An early example of the connection between inauthenticity and capitalism was made by Karl Marx, whose notion of "alienation" can be linked to the later discourse on the nature of inauthenticity.

To place authenticity side by side with African culture therefore remains contextual and ad rem. The questions remain how Africa can remain authentic to its culture. The African culture has undergone several upheavals and revolutions, and like the Israelites lost her identity in colonial exile- language, religion, ethics, norms, morals, social life etc have been lost not only to the West but also to Africans. The African continent subjects herself daily to self-colonilization. A situation where we see our language, our mode of interaction, our communal responsibilities as ideas that are archaic and ante-modernism and must be discarded. This affected our past, is affecting our present and is likely to mar the African cultural future if care is not taken. Failing to work would be an attempt to confirm Naipul's concept that "Africa has no future" (Naipul, 1979). Indeed we have a future and we must work to defend this fact, we must work to defend the responsibilities that our future presents.

\subsection{Culture}

Culture is the totality of learned, socially transmitted customs, knowledge, material objects and behaviour. It includes the ideas, value, customs and artifacts of a group of people. Charles Taylor defined it as "that complex whole which includes knowledge, belief, art, law, morals, custom, and any other capabilities and habits acquired by man as a member of society"(Taylor, 1991). Culture is a pattern of human activities and the symbols that give these activities significance. It is what people eat, how they dress, beliefs they hold and activities they engage in. It is the totality of the way of life evolved by a people in their attempts to meet the challenges of living in their environment, which gives order and meaning to their social, political, economic, aesthetic and religious norms and modes of organisation thus distinguishing people from their neighbours. Culture comprises material, institutional, philosophical and creative aspects. The process of expanding culture has been under way for many centuries, but technologies have increased the speed and have also broadened the distribution of cultural elements beyond communities and nations' territorial frontiers. However, culture can be transmitted or acquired through information or symbol. Cultural identity according to Richard are those "attributes, behavioural patterns, lifestyles, social structures and norms that distinguish a people from other peoples" (Richard, 1997). These are passed on literally or inherited from one generation to another (cultural heritage), or horizontally passed on from one society to another through such agent as globalization.

\section{Issues in Culture and the Call for Authenticity}

\subsection{Cultural Relativism}

Cultural relativity is the ability to study and describe another society/culture from its point of view without imposing ones own cultural values on those descriptions and analysis. We have to be able to put aside our own cultural concepts in order to analyse and then describe the society that we are studying. This could prove hard for some, depending on the circumstances. In some cultures, it is considered perfectly normal for the women to be subservient and meek, in most of the modern western world it is not, there are exceptions to this though.

To assume pleasure in the Somali world for example is equal to pleasure in the Western context is to assume a normality or expectation across cultures. If all humans are equal then the direction in which sexual pleasure take in the Somali community cannot be compared to those of the Western World, which places the female orgasm as being central to the female sexual experience; which parallels the male sexual experience.

Duelo 1997, posits that the principle of cultural relativity does not mean that "because the members of some savage tribe are allowed to behave in a certain way that this fact gives intellectual warrant for such 
behavior in all groups". Cultural relativity means, on the contrary, that “...the appropriateness of any positive or negative custom must be evaluated with regard to how this habit fits with other group habits" (Kinoti, 2007). Having several wives for instance, makes economic sense among herders, not among hunters. While breeding a healthy skepticism as to the eternity of any value prized by a particular people, anthropology does not as a matter of theory deny the existence of moral absolutes.

A classic example of cultural relativity is what was observed by psychologist Gregory Bateson, in traditional Balinese families, mothers routinely stroke the penises of their young sons, and such behaviour is considered no more incestuous than breast-feeding. Incest is also not illegal in Israel, perhaps a response to the low population issues. So we see as Sam Vaknin suggests taboos or in this case lack of taboo, do ultimately respond to necessity.

In many African countries woman may gain their satisfaction from her husband's orgasmic intensity, knowing he has enjoyed intercourse with them. It is not that they cannot also have orgasms, but the value attached to it is different; sex after all is a state of mind. In some parts of Somalia women put special herbs in their vagina to cause tightness for their husbands. Some feminist will rush to label this as a form of oppression, but not if cultures are valued as equals and understood in context of plurality. How can a Western woman dictate to an African woman how she should experience sexual pleasure? And even within Western culture we see complex sexual roles of domination and bondage. And this is why the issue of so-called female genital mutilation becomes an issue as outlined in the groundbreaking work of Fuambai Ahmadu and Wairimu Njambi. The only stipulation is choice and access to a full discourse of information from within that culture. But the minute the Somali woman leaves Somalia she is confronted with a Western world screaming "oppression", she is then forced to review her culture. All the while the Western woman is rushing to the Designer Vagina clinic to get the very procedure done that the Somali woman has been doing for centuries.

\subsection{Africa and Corrupted Cultures}

Cultural corruption and super-imposition is when elements of a culture are replaced with similar customs which have completely different attachments. Traditionally in some African communities alcohol served as a way in which certain ordained spirit people communed with the other realms: Alcohol (palm wine) served as a purely "religious" function in the society. A way of specifically relating to another world in specific rituals by specific people. With the coming of the European alcohol began to take on a new function as a social drink. The trade in slaves for alcohol created a commercial grade brew which was shifted out of the religious realm to exacerbate and encourage social drinking. This only increased with the depression from the trauma of slavery and colonialism dug deeper into African communities.

Some would point to the Libation rituals, but the pouring of alcohol became a form of corrupted culture. This became so common. It actually gives the illusion of being part of traditional African culture. However the social drinking was never a mainstay of African culture. The consequences of this alteration to cultural purpose are a form of cultural corruption by superimposing other cultural values in place of pre-existing similar cultures. i.e. usage of alcohol. Because alcohol was actually almost never recreational, and only certain people drank it. So we are talking about a cultural/spiritual context for a fermented brew to gain access to the spiritual world, which is now used for fun; just like our African music today.

\subsection{Changing Face of Culture}

If a fish jumps out of the sea and grows wings, feathers and a beak, at some point in that change the fish ceases to be a fish - culture is no different 'We must identify what we are discussing when we saw cultures change. Cultural diffusion looks at how cultural changes spread from a small source sample from one society to another. The process by which discrete culture traits are transferred from one society to another, through migration, trade, war, or other contact'

Here, some scholars suggests two types of change "off Axis change" and "on axis change", where the axis is the core value formation of a culture because we run the risk of making an error of confusion of cultural innovation with radical core changes. For example Franz Boas viewed culture as consisting of countless loose threads, most of foreign origin, but which were woven together to fit into their new cultural construction. Discrete elements which become more interrelated as time passes--blurring their discreetness in the process. Now on axis change allows these elements as Boas notes to be woven together under the authorship of the people receiving innovations. In the off-axis setup this process is overwhelmed by imposition.

Christianity has radically "changed" the Gikuyu culture in Kenya. Yet the ancient Gikuyu would still recognize Gikuyu of today as their relatives. The language, the core customs and rituals, even with the Christian faith are still recognizable. While subjective, the same cannot be said for the forced African Diaspora who would be unrecognizable to say they are Akan people in Ghana. In marriage cultures all over Africa cows as a dowry gift has been replaced by blankets (especially in Southern Africa) and money. This is the cultural response to practical changes in world currency. However, that is not a core change since the spirit of labolla/mahr/dowry remains. The principles of a wedding gift remain despite a change in currency. The world has swung left and right but culture of marriage is over 7000 years old.

When a culture no longer meets the need of a people or solve the problem confronting a people, notes Amos Wilson, that culture must transform. Technology has altered much of our landscape, people in Gambia 
now go to the Mosque by car as oppose to by horse. People talk on mobile phones, but the greetings are still "Assalam Alaikum." Technology has shaped the culture but it has not made a significant change to the core Islamic faith, despite the Adhan now being called out on a loud speaker and electricity being in every Mosque. That People now read the bible on Ipads is an evolution but not a change which suggests Christianity is becoming Scientology.

Between Monday and Friday every person undergoes "change" it however would be a misrepresentation of the facts to suggest that this "change" means that people become radically different individuals. The cliche which expresses "cultures change they are not static"' is being abused to justify radical alternation to African cultures. So the barriers which protect African identity are now being torn down under the word "cultures are not static." New markets and foreign destructive habits can now nest in African societies under the banner of "cultures change." But cultures even if they change should always change under the process of agency. There is no dispute that cultures adapt and evolve and reply to reality, but they ethics are pretty much rooted in the original foundational paradigm which fostered them. Everything changes and there is a degree of subjectivity, but a change must be weighed unless we confuse natural variations and adaptations with some notion of Darwinian evolution. And at the end of the day it is called "African" culture for a reason greater than it being a black step-child of European culture.

\subsection{Cultural Imperialism}

Cultural imperialism is the domination of one culture over another other by a deliberate policy or by economic or technological superiority. Africa is undoubtedly the victim of cultural imperialism and its mechanisms today are none other than globalization. The agents of this imperialism are mass media and unfair trade. The consequences of this imperialism are under-development, lost of identity and language and destruction of markets (e.g. where traditional African clothes are replaced with Western ones).

\subsection{The Authentic Virtues and Values of Traditional African Society}

In striving to prove the authenticity of the African culture or in the bid to restoring its authenticity deep considerations must be made on the core ethical or moral roots of the Africa. Cut away from its core ethical roots the African cultural is stripped of values. In Africa's morality is rooted authenticity. It is an aspect of life that has continued to extol the African man, even in his poverty and political incapacitation. However there seems to be a lacuna. It seems as if something important has disappeared and nothing has replaced it.

In traditional Africa, a shared morality was the cement of society. Some of the values of traditional African society include, Charity, honesty, hospitality, generosity, loyalty, truthfulness, solidarity, and respect for nature, elders and God. However Kinoti notes that "there were also personal values which assisted the individuals to be integrated, like honesty, reliability, generosity, courage, temperance, humanity and justice and social values that helped society to remain integrated like peace, harmony, respect for authority, respect for and fear of supernatural realities"(Kinoti, 2007). These values inherent in the traditional African society give Africa a true prestige more than any other society of the world. Majola adds to the lists; "harmony, peace, friendliness and decency"(Majola, 1988). Gyekye included "kindness, compassion, benevolence, concerns for others"(Gykeye,1998).According to him any action or behavior that is conducive to the promotion of the welfare of others, and also imposes a duty to the community and its members; Interdependence, co-operation and reciprocity.

Inherent in the traditional African concept of virtuous life is "the ten commandments, like prohibition to steal, murder, commit adultery, tell lies or deceive”(Gelfand,1987). Gelfand placed the virtues side by side with their vices. For him the most important virtues are "respect, love, compassion, kindness, generosity, truth, rectitude, humility, self-discipline, forgiveness, mercy, pity, sufficiency, repentance, trust, giving, strength, patience, courage, hard work, unselfishness and the willingness to share whatever one has, no matter how little it may be"(Gelfand,1987). The vices rejected by traditional society were "abuse, lying, deceit, stealing, adultery, drinking, violent quarreling, pride, jealousy, covetousness, hatred, ingratitude, anger, negligence, weakness, assault, provocation and selfishness"(Gelfand, 1987). Geldfand also mentions different types of sanctions designed to ensure proper behavior. One of them is "public ridicule to cause shame, guilt and fear and to prevent antisocial behavior". He discusses how morality was enforced in detail, and distinguishes between two main types of sanction; religious and social.

Religious Sanctions included the practice of cursing through magic and the fear of punishment by the ancestors and the gods-the policemen of traditional Africa. Social sanctions included the following 1. Praising and honouring the good and brave 2. Parental gifts to good and reliable children 3. Confidence between parents and children. However, there were negative social sanctions like family or clan renunciation, disinheriting, swearing of oaths and curses, ostracism and public disgrace in notorious criminals, adulterers, seducers etc

\subsection{Characteristics of Traditional African Morality}

Having looked keenly into the inherent values of traditional African Society, this article goes on to x-ray the characteristics that encapsulates those values as they define the authentic culture of the African society. The morality of the African Traditional society is culturally founded as it is communalistic, humanistic or 
anthropocentric, pragmatistic and utilitarian, Tribalistic and Shame Oriented. This article is consigned mainly with two [communalistic and humanistic] characteristics as they inform the authenticity of the African Culture.

\subsection{Communalistic}

The moral foundation of African culture across the African world is communal based. So fundamental is in informing African ethics that everything; dance, music, marriage is impacted upon. Music is communal, harvesting crops is communal, even eating is communal: every ritual and rite is tied into bonding and reaffirming communal bonds. For instance, when people say Gay Marriage is un-African, despite their inability to articulate it beyond "un-African," they are speaking to the moral communal foundation of African societies which always place the community above the individual. Rights also cannot supersede those "rights" ordained in nature; those things which are incompatible with people hood are therefore generally incompatible with African values. And in this communal setting, marriage for example is a coming together of communities, via two individuals, with the promise of people hood.

Kollman (1988) notes that "African morality and ethics cannot be conceived outside of the community" [59]. However the characteristic of communalisms is not only outstanding but serves as its defining characteristic. Thus, traditional African society was characterized not by one's own rights but by duties towards others. Gyekye, notes this distinctly; "If I carry out a duty to help someone in distress, I would not be doing so because I think a person has right against me, a right I should help to fulfil. I would be carrying out that duty because I consider that person worthy of some moral consideration by me...." (Gyekye, 1988). In affirmation to this Wiredu, notes that "the communalistic orientation means that an individual's image will depend rather crucially upon the extent to which his/her action benefit others rather than him/herself, not of course, by coincidence, but by design"(Wiredu,1997).Here an individual who remained content with self regarding success would be viewed as so circumcised in outlook as not to merit the title of a real person. By this Wiredu is also of the opinion that African traditional morality is quintessentially social. Motlhabi agrees with Wiredu that "...the central moral norms were the maintenance of harmonious relationships within the community”(Motlhabi,1986).

However a communalistic ethics or morality does not only entail that all human behavior should be to the benefit of society. Society itself is also the norm for moral behavior. Majola is of the strong view that "the criterion of morality is the community"(Majola,1988). In accordance to this, He pointed out that an act is right if and only if it also conforms to the rules and regulations established by the community. Kigongo stresses the fact "that in a society-like the present African one-Where there is rapid and profound social changes and fundamental conflicts in people's social experience, one's ability to make choices in respect of moral behaviour is of paramount importance"(Kigongo, 1991). Traditional morality did not prepare Africans for such choices because it emphasized conformity to the status quo and punished non-conformity.

\subsection{Humanistic}

In stressing the authenticity of African culture in relation to morality Wiredu points out that African concept of morals are generally of humanistic orientation. According to him at, all ages morality is grounded in conceptual and empirical considerations about human well-being. Thus, "a human person is essentially the center of the thick set of concentric circles of obligations and responsibilities matched by rights and privileges revolving round levels of relationships irradiating from the consanguinity of household kith and kin, through the 'blood' ties of lineage and clan, to the wider circumference of human family hood"(Mojola, 1988). Mojola however agrees that "because of its preoccupation with human welfare and well-being, traditional morality was essentially humanistic and 'man centered"(Mojola,1988). Bujo in the same vein describes traditional African ethics as fundamentally "anthropocentric and humanistic"(Bujo, 1990). in other words a horizontal African relationship between humans. The concept of Ubuntu according to Motlhabi "placed emphasis on the person as the highest and intrinsic value'(Motlhabi, 1986).

\section{Back to Authenticity; Re-Examining the Basic Problems Inherent in African Culture 3.1. Africa and Moral Crises}

There is the existence of moral crises in the African cultural / traditional society. There has been a shift from the status quo. The west is been accused for this basic problem. The western secular culture spurred by individualism and capitalism has been the sole contributor to the basic moral problem of the African society. The forces involved here are external because they come not from inside Africa but from outside. This possesses a question on the authenticity of the African culture.

According to Mwikamba, whereas in the past, "Africans were much more community-centered, today they are more and more ego-centered”(Mwikamba, 1992). This was captured vividly by Bennaars when he said "In traditional Africa, Morality was always intrinsically linked to the community. The sole criterion of goodness was the welfare, the well-being of the community. Any form of individualism was seen to have a negative value; it was seen as a potential threat and thus regarded as intolerable" [1993]. But the case today has been a different and controversial one as "individualism in various forms is increasingly evident in daily life, education, religion; culture imposed from outside have all contributed, not to speak of economics and 
politics. Today, African individualism has largely replaced communalism, as both individuals and nations struggle for survival"(Oruka,1990). Hence Oruka draws attention to the implication of such bizarre situation. According to him, "for society so seriously disturbed by invasion of a foreign culture to come back to cultural normality, it needs at least to pass through five generations or a hundred years"(Oruka, 1990). What this implies to the African society given the modernity crises her culture faces is "total annihilation of the African culture"(Kigongo,1991) because trying to solve the problem would lead to infinite regress. However, the African culture could regain back its authenticity by laying deep considerations on the issues below.

\subsection{Materialism}

One of the clearest influences from the West is the growing Materialism in Africa. Money and Material well being have become a semi-god in such a way that the cultural values are been replaced with the mundane. Economic activity, success and material gain have become ends in themselves. People are subordinating and exploiting others for economic purpose. Materialism and consumerism erode the traditional morals. Hedonism has the upper hand. The idols which the African youth imitate are the business, sex, music and football idols from the West. Human sexuality becomes a tool to be used and discarded; sexual violence, incest and rape are on the high increase. Unfortunately these ills have replaced the cultural values of the traditional African society. The love for hard work that was foundational to the strength of the African is been replaced with getrich quick syndrome [money doubling, kidnapping, ritual], the slang yahoo-boys has been adopted to describe group of boys and young men whose quest for money and wealth is insatiable, the respect for marriage and sex as sacred is been replaced with animalistic desires, the quest for justice and equity is been replaced with bribe and total corruption. Thus, the authenticity of the African cultural values is been stripped off its essence on daily bases.

\subsection{The Mass Media/Internet}

Technology has made it possible for the average African man to acquire gadgets that serve as means of communication and information. This in a very large extent has continued to help the African man to improve his means of livelihood. Unfortunately, the adverse effects of the mass media [televisions, videos, and internet] have remained devastating in the recent years. They propagate the secular moral values. Young people in Africa become die-hard worshippers of Western ideals because they are considered to be modern. There are no longer censorships on what goes into the market and on what goes on, on the screens of televisions. Nude Dances, pornographies are often seen in every channel in cables like Dstv, Mitv, Star Tv, or even our local channels. This is been taken to be the modus Vivendi of the modern world, while our values are crumbling, the values of respect for the human body and parts, the values for decency.

\subsection{Character Education}

The impact of education in Africa has been enormous. It has gone a long way to give the African man a high sense of intellectual independency and liberated him from the shackles of ignorance at least with regards to the intellect, unlike what use to be the case in movies like 'The gods must be crazy', show casing the traditional Kenyan Society. However Kigongo, points out that "such education only provided intellectual or professional training without any moral education for life" (Kigongo, 1991). Here we are interested in the character education of the African. Because it tends at producing an integral personality and authentic society.

\subsection{Home Training}

The family as it is forms the core of the traditional African society and it is from the family that the child gets his foundational socialization. The child is taught how to do house chores, go to the stream, cook and go to the farm. The Child is made to acquire the nubs and values of the society. Home training has a cultural undertone to African society, the American Parents can never waste time teaching or giving the child home training, because it is of little or no value to him, but it is foundational to the African society, but unfortunately the positive attitude is departing our culture and our society. The respect for elders and sacred things, the taking to heart of counselling of the elders and traditional custodians [Nka din a nti], [Ntiwunka], the love for collective responsibilities, the respect for others properties etc. These and many more authentic African virtues and values must be restored lest the African traditional values undergo a re-colonization.

\section{Conclusion}

African culture must retain its fundamental ethos while positively interacting with the surrounding economic, social and political landscape each generation finds itself in. The traditions must first be understood in order to be successfully modified to the prevailing challenges of each generation. So as much as cultures are not static there is a moral or ethical thread that must always be preserved. Cultures cannot change so much that they become useless in preserving and reflecting a rich African heritage in which the sanctity of life is central. And within Pan-Africanism the opportunities are plenty for the best applicable traditions to be practiced, absorbed and continued. And who are better to govern that beautiful cultural journey, than African people? 
This article centers on pressing issues concerning Africa, with special emphases on Culture. Here the statement of the problem remains the possibility of Cultural Authenticity in Africa. Obviously Authenticity is possible if and only if there is the proper and unbiased re-assessment of values that have for centuries remained the pride of the continent. Africa unequivocally, possesses values second to none in the world and these values must be retrieved if Africa is to rise again. The study concludes that the key to recovering the African Cultural Authenticity is by deconstructing colonial experiences [of slavery, economic exploitations, religion imposition, torture, hard labour, harassment etc], re-imbuing her with the strengths of yesterday's myths [genius of our ancestors], using her culture [way of living and doing things, values, standards, ideals and ethics] as the matrix of restoring her authenticity and constructing her future. This is the only way to save Africa and this crusade must be carried out by us-the Africans.

No one thing on its own will liberate a person. Wearing African clothes is important, but wearing African manners is even more important. All these things go together-the names, the socialization, the culture, the God-consciousness, the community. And any step which brings anyone closer to that identity which was ripped away in 500 years of violence is a step in the right direction.

We must return to being African, but not "African" 10,000 years ago or even 150 years ago. But a future African, as if our journey was never violently interrupted.

\section{References}

Alexander, N. (1999). Virtues of authenticity essays on Plato and Socrates. Princeton: Princeton University Press.

Naipul, V.S. (1979). An interview with on. Available from: www.nytimes.com/books/98/06/07/naipulmeeting.html. [Accessed 13 ${ }^{\text {th }}$ May 1979]

Bujo, B. (1990). African Christian morality at the age of inculturation. Narobi: St Paul.

Gelfand, (1987). The genuine Shona: Survival values of an African culture Gweru. Zimbabwe: Mambo.

Howard, V. \& Edna, H. (1975). Subjectivity/objectivity. Søren Kierkegaard's Journals and Papers.Indiana University Press.

Kigongo, K. (1991). Ethical education in the reform of secondary education in Uganda Kampala: Makerere University.

Kinoti, F. (2007). The investigation of morality in Africa. Accra: Immason.

Lee, V. (2003). What is authenticity in discourse studies. Switzerland: Princetonvil.

Magesa, L. (1997). African religion: The moral traditions of abundant life. New York: McGraw.

Mojola, A. (1988). Introductory ethics for college students and teachers in Nairobi. Nairobi: Heinemann.

Motlhabi, M. (1986). The concept of morality in African tradition. Michigan: Grand Rapids Eardans.

Mwikamba, C. (1992). Changing morals in Africa. Nairobi: Kenya.

Oruka, H. (1990). Ethics a basic course for undergraduate studies. Nairobi: Narobi University Press.

Richard, P. (1997). Creating country music: Fabricating authenticity Chicago: University of Chicago Press.

Taylor, C. (1991). The ethics of authenticity. Massachusetts: Harvard University Press. 